\title{
Neutrofil Darah Tepi pada Pasien Kanker Payudara Stadium Lanjut Sebelum dan Sesudah Dilakukan Tindakan
}

\author{
${ }^{1}$ Rizky Asri, ${ }^{2}$ Victor Pontoh, ${ }^{2}$ Marselus Merung \\ ${ }^{1}$ PPDS Ilmu Bedah Fakultas Kedokteran Universitas Sam Ratulangi Manado \\ ${ }^{2}$ Divisi Bedah Onkologi Bagian Ilmu Bedah Universitas Sam Ratulangi/RSUP Prof. Dr. R. \\ D. Kandou Manado \\ Email: rizkyasri88@gmail.com
}

\begin{abstract}
Worldwide, there were around 2.1 million breast cancer cases diagnosed in 2018 . There was nearly 1 of 4 cancer cases among women with an incidence of 38,1 per 100.000 and mortality of 14,1 per 100.000 . This study was aimed to determine whether there was a change in response score of systemic inflammation by using peripheral blood neutrophil level in female patients with advanced stage of breast cancer before and after treatment. This was an interventional analytical study with a cross sectional design, conducted at Prof. Dr. R. D. Kandou Hospital Manado. The results showed that there were 43 patients in the period of May 2018 to August 2018. The youngest age was 34 years and the oldest age was 70 years with a mean of 52.16 years $(\mathrm{SD} \pm 10.002)$. The most frequent stage was III B $(58.1 \%)$, followed by IIIC (25.6\%), IIIA (11.6\%), and IV (4.7\%). Before treatment, the highest level of neutrophil was $55 \%$, the lowest level was $12 \%$, with a mean of $27.84 \%$ ( $\mathrm{SD} \pm 10.005)$. After treatment, the highest level of neutrophil was $45 \%$, the lowest level was $11 \%$, with a mean of $22.7 \%$ $(\mathrm{SD} \pm 6.635)$. The paired-t test showed a very significant difference in peripheral blood neutrophil level between before and after treatment $(P<0.001)$. Conclusion: There was a significant decrease of peripheral blood neutrophil level in breast cancer patients after treatment.
\end{abstract}

Keywords: plasma neutrophil, advanced stage of breast cancer

\begin{abstract}
Abstrak: Di seluruh dunia, terdapat sekitar 2,1 juta kasus kanker payudara wanita yang didiagnosis pada tahun 2018, serta terhitung hampir 1 dari 4 kasus kanker di kalangan wanita dengan insidensi 38,1 per 100.000 dan kematian sebanyak 14,1 per 100.000. Penelitian ini bertujuan untuk untuk menilai adanya perubahan skor respons peradangan sistemik dengan menggunakan kadar neutrofil darah tepi pada pasien kanker payudara stadium lanjut sebelum dan setelah terapi. Jenis penelitian ialah intervensional analitik dengan desain potong lintang, yang dilakukan di RSUP Prof. Dr. R. D. Kandou Manado. Hasil penelitian mendapatkan 43 pasien sejak Mei 2018 s/d Agustus 2018. Usia termuda 34 tahun dan usia tertua 70 tahun dengan rerata usia 52,16 tahun ( $\mathrm{SD} \pm 10,002)$. Stadium terbanyak ialah stadium IIIB $(58,1 \%)$, diikuti stadium IIIC $(25,6 \%)$, stadium IIIA $(11,6 \%)$, dan stadium IV $(4,7 \%)$. Sebelum dilakukan tindakan didapatkan kadar neutrofil tertinggi 55\%, kadar terendah $12 \%$, dan rerata 27,84\% (SD $\pm 10,005)$. Setelah dilakukan tindakan didapatkan kadar neutrofil tertinggi $45 \%$, terendah $11 \%$, dan rerata $22,7 \%$ (SD $\pm 6,635$ ). Hasil uji t berpasangan mendapatkan perbedaan yang sangat bermakna dari kadar neutrofil sebelum dan sesudah terapi $(P<0,001)$. Simpulan: Terdapat penurunan bermakna dari kadar neutrofil darah tepi pada pasien kanker payudara setelah dilakukan tindakan.
\end{abstract}

Kata kunci: neutrofil darah tepi, kanker payudara stadium lanjut 
Di seluruh dunia, terdapat sekitar 2,1 juta kasus kanker payudara wanita yang baru didiagnosis pada tahun 2018, terhitung hampir 1 dari 4 kasus kanker di kalangan wanita dengan insidensi 38,1 per 100.000 , dan kematian sebanyak 14,1 per 100.000 . Penyakit ini merupakan keganasan yang paling sering didiagnosis di sebagian besar negara (154 dari 185) dan juga merupakan penyebab utama kematian akibat keganasan di lebih dari 100 negara dengan pengecualian utama ialah Australia/Selandia Baru, Eropa Utara, Amerika Utara (didahului oleh kanker paru), dan banyak negara di Afrika Sub-Sahara (karena tingginya tingkat kanker serviks). Angka kejadian kanker payudara yang tertinggi di Australia/ Selandia Baru, Eropa Utara (mis. Inggris, Swedia, Finlandia, dan Denmark), Eropa Barat (Belgia dengan tingkat global tertinggi, Belanda, dan Prancis), Eropa Selatan (Italia), dan Amerika Utara. Dalam hal kematian, tingkat kanker payudara menunjukkan variabilitas yang lebih rendah, dengan kematian tertinggi diperkirakan di Melanesia, di mana Fiji memiliki tingkat kematian tertinggi di seluruh dunia. ${ }^{1-3}$

Kanker payudara merupakan salah satu penyebab utama kematian wanita di seluruh dunia. Tingkat ketahanan hidup 5 tahun mendekati $97 \%$ ketika sel-sel tumor terbatas pada jaringan payudara, dan akan menurun secara dramatis menjadi $23 \%$ ketika sel-sel tumor telah bermetastasis ke organ-organ lain pada saat diagnosis. ${ }^{4}$ Metastasis kanker payudara cukup kompleks dan merupakan proses multisteps yang membutuhkan ekspresi gen-gen spesifik. ${ }^{5}$

Telah diketahui bahwa variasi hasil luaran pasien kanker tidak semata ditentukan dari karakteristik tumor tetapi juga faktor respons inang. Kanker payudara ialah jenis kanker yang paling umum pada wanita dan risikonya meningkat seiring bertambahnya usia. Seperti pada tumor lainnya, perkembangan kanker payudara dikaitkan dengan peradangan sistemik. ${ }^{6}$ Keadaan inflamasi mempercepat pertumbuhan tumor, invasi, angiogenesis, dan bahkan metastasis. Peningkatan petanda peradang- an berhubungan dengan menurunnya ketahanan hidup pasien kanker payudara. Terdapat hubungan antara petanda peradangan sederhana (seperti neutrofil, limfosit, dan trombosit darah tepi) dengan hasil luaran kanker. ${ }^{7,8}$

Terdapat beberapa penelitian yang mengukur petanda peradangan untuk mencari kaitan prognostik independen pada berbagai kanker lanjut, salah satu diantaranya ialah neutrofil. ${ }^{8,9}$ Hubungan antara tingginya rasio neutrofil dengan limfosit dan buruknya prognosis sangat kompleks. Pada percobaan kultur neutrofil dan limfosit dari donor pasien kanker, neutrofil terkait tumor melalui reaksi enzimatik, juga menjadikan pembentukan matriks ekstrasel baru, yang menghasilkan pelepasan faktor pertumbuhan fibroblas dasar, migrasi sel endotel, dan disosiasi sel kanker. Selain itu, spesies oksigen reaktif yang dihasilkan neutrofil menurunkan sifat adhesi dan properti promosi dari matriks ekstrasel, serta melalui aktivasi nuclear factor (NK)$\mathrm{kB}$, menghambat apoptosis sel tumor. Peristiwa ini mengakibatkan peningkatan angiogenesis, pertumbuhan tumor, dan perkembangan ke fenotip metastatik. Pada kanker payudara, oncostatin $M$ yang disintesis oleh neutrofil memberi sinyal ke selsel payudara untuk menghasilkan vascular endothelial growth factor (VEGF) dan meningkatkan pelepasan sel kanker. ${ }^{10}$

Dalam lima tahun terakhir, hasil prognosis pasien kanker khususnya kanker payudara stadium lanjut telah dilaporkan baik dengan menggunakan rasio neutrofil sebagai prediktor yang terpisah. Nilai neutrofil praoperasi dapat berkontribusi pada dokter bedah untuk diagnosis dan prognosis pada kanker payudara yang terkait dengan peradangan karena semua efek peradangan ini menyebabkan peningkatan neutrofil darah tepi. ${ }^{6}$ Penghitungan neutrofil ialah metode yang nyaman dan murah, serta dapat menunjukkan hubungan dengan peradangan dan tumor. Penelitian ini bertujuan untuk menggunakan kadar neutrofil darah tepi sebagai sistem skoring inflamasi sistemik untuk menganalisis perubahan yang terjadi sebelum dan setelah 
tindakan pada pasien kanker payudara stadium lanjut.

\section{METODE PENELITIAN}

Penelitian ini ialah intervensional analitik dengan desain potong lintang untuk menilai adanya perubahan skor respons peradangan sistemik pada pasien kanker payudara stadium lanjut sebelum dan setelah tindakan.

Penelitian dilakukan di RSUP Prof. Dr. R. D. Kandou Manado. Subjek penelitian ini ialah semua pasien wanita dengan kanker payudara stadium lanjut yang memenuhi kriteria penelitian dalam periode Mei s/d Agustus 2018.

Data subyek penelitian dicatat pada formulir penelitian untuk pengelompokkan, penyuntingan, dan pengkodean kemudian diolah menggunakan program SPSS versi 22.0. Analisis data yang digunakan ialah analisis deskriptif dan analisis perbandingan data sebelum dan sesudah tindakan dengan uji t berpasangan, dan nilai kemaknaan $\alpha=0,05$.

\section{HASIL PENELITIAN}

Selama masa penelitian Mei 2018 sampai Agustus 2018 terdapat 43 pasien yang memenuhi kriteria inklusi dan eksklusi. Usia termuda ialah 34 tahun dan usia tertua 70 tahun dengan rerata usia 52,16 tahun $(\mathrm{SD} \pm 10,002)$. Stadium terbanyak ialah stadium IIIB pada 25 pasien (58,1\%), diikuti stadium IIIC 11 pasien $(25,6 \%)$, stadium IIIA 5 pasien $(11,6 \%)$, dan stadium IV 2 pasien (4,7\%) (Tabel 1).

Tindakan yang paling sering diberikan berupa kombinasi kemoterapi dan operasi $(\mathrm{K}+\mathrm{O})$ sebanyak 40 pasien $(93 \%)$, kemo- terapi saja (K) 2 pasien $(4,7 \%)$, dan operasi saja (O) 1 pasien $(2,3 \%)$ (Tabel 2).

Hasil pemeriksaan jumlah leukosit mendapatkan hasil terendah ialah $200 / \mathrm{mm}^{3}$, tertinggi $38.000 / \mathrm{mm}^{3}$, dan rerata $9968 / \mathrm{mm}^{3}$ $\left(\mathrm{SD} \pm 8045,368 / \mathrm{mm}^{3}\right)$.

Tabel 1. Jumlah dan frekuensi stadium kanker payudara

\begin{tabular}{ccc}
\hline Stadium & Frekuensi & Persentase \\
\hline IIIA & 5 & 11,6 \\
IIIB & 25 & 58,1 \\
IIIC & 11 & 25,6 \\
IV & 2 & 4,7 \\
Total & 43 & 100,0 \\
\hline
\end{tabular}

Tabel 2. Jumlah dan frekuensi tindakan yang diberikan pada subyek penelitian

\begin{tabular}{ccc}
\hline Tindakan & Frekuensi & Persentase \\
\hline $\mathrm{K}$ & 2 & 4,7 \\
$\mathrm{~K}+\mathrm{O}$ & 40 & 93,0 \\
$\mathrm{O}$ & 1 & 2,3 \\
Total & 43 & 100,0 \\
\hline
\end{tabular}

Sebelum dilakukan tindakan didapatkan kadar neutrofil tertinggi 55\%, kadar terendah $12 \%$, dan rerata $27,84 \%$ (SD \pm $10,005 \%)$. Setelah dilakukan tindakan didapatkan kadar neutrofil tertinggi $45 \%$, kadar terendah $11 \%$, dan rerata $22,7 \%$ (SD士$6,635 \%$ ) (Tabel 3). Karena ukuran sampel $(\mathrm{n})=43>30$, maka tidak dilakukan uji kenormalan data. Perbedaan data neutrofil sebelum dan sesudah tindakan diuji dengan uji $\mathrm{t}$ berpa-sangan yang menyatakan terdapat perbeda-an yang sangat bermakna dari kadar neutrofil sebelum dan setelah tindakan $(P<0,001)$ (Tabel 3).

Tabel 3. Hasil uji perbedaan neutrofil sebelum dan sesudah tindakan

\begin{tabular}{lccc}
\hline \multirow{2}{*}{ Statistik } & \multicolumn{2}{c}{ Kadar netrofil } & \\
& $\begin{array}{c}\text { Sebelum } \\
\text { tindakan }\end{array}$ & $\begin{array}{c}\text { Sesudah } \\
\text { tindakan }\end{array}$ & Uji t \\
\hline Minimum & 0,12 & 0,11 & \\
Maksimum & 0,55 & 0,45 & $\mathrm{t}=6,596$ \\
Median & 0,27 & 0,24 & $(P<0,001)$ \\
Rerata & 0,278 & 0,227 & \\
Simpangan Baku & 0,1001 & 0,0663 & \\
\hline
\end{tabular}


Jadi, kadar neutrofil mengalami penurunan yang sangat bermakna pasca tindakan (Gambar 1).

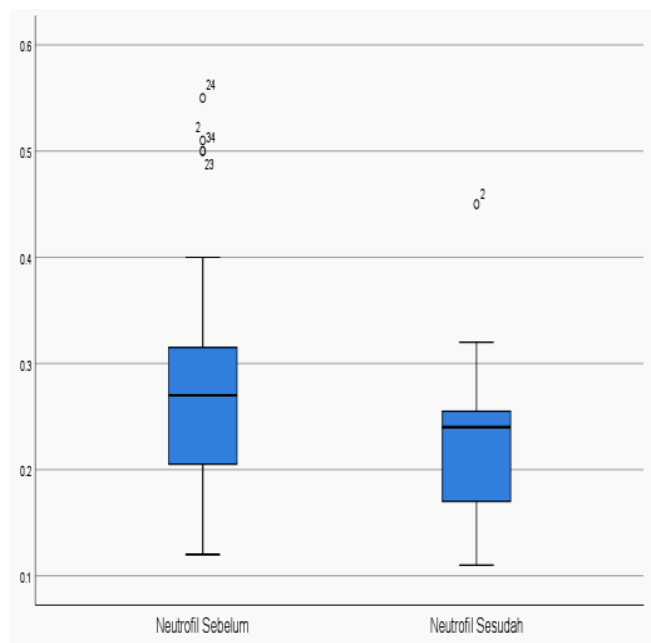

Gambar 1. Grafik box-whisker sebaran data neutrofil sebelum dan sesudah tindakan

\section{BAHASAN}

Selama masa penelitian Mei 2018 sampai Agustus 2018, didapatkan 43 pasien yang memenuhi kriteria inklusi dan eksklusi. Usia termuda ialah 34 tahun dan usia tertua 70 tahun dengan rerata usia 52,16 tahun ( $\mathrm{SD} \pm 10,002$ tahun). Stadium yang terbanyak ialah stadium IIIB $(58,1 \%)$, diikuti stadium IIIC $(25,6 \%)$, stadium IIIA $(11,6 \%)$, dan stadium IV (4,7\%). Menurut laporan American Cancer Society (ACS) mengenai Breast Cancer Facts \& Figures 2017-2018, selama 2010-2014, usia rerata diagnosis kanker payudara ialah 62,17 tahun. Hal ini berarti bahwa setengah dari perempuan yang menderita kanker payudara ialah 62 tahun atau lebih muda pada saat didiagnosis. Median usia diagnosis lebih muda untuk perempuan kulit hitam daripada yang berkulit putih. Hasil penelitian ini tidak sejalan dengan penelitian ACS yaitu diagnosis kanker payudara ditemukan pada usia lebih dini, yang menunjukkan kemungkinan faktor risiko lokal yang menyebabkan tingginya insidensi pada usia yang lebih muda. Kemungkinan lain ialah tingkat kejadian untuk kanker payudara dengan stadium manapun menurun di semua kelompok secara global. Penurunan tersebut dapat mencerminkan pergeseran menuju tahap lebih dini saat didiagnosis. ${ }^{11,12}$

Kelangsungan hidup pasien kanker payudara bervariasi berdasarkan stadium saat diagnosis. Tingkat kelangsungan hidup relatif 5 tahun secara keseluruhan ialah 99\% untuk penyakit lokal, $85 \%$ untuk penyakit regional, dan $27 \%$ untuk penyakit tahap jauh. Kelangsungan hidup dalam setiap tahap bervariasi berdasarkan ukuran tumor. Sebagai contoh, di antara wanita dengan penyakit regional, kelangsungan hidup relatif 5 tahun ialah $95 \%$ untuk tumor berukuran $\leq 2,0 \mathrm{~cm}, 85 \%$ untuk tumor berukuran $2,1-5,0 \mathrm{~cm}$, dan $72 \%$ untuk tumor yang berukuran $>5,0 \mathrm{~cm} .^{13}$

Pada penelitian ini, sebelum dilakukan tindakan didapatkan kadar neutrofil tertinggi $55 \%$, kadar terendah $12 \%$, dan rerata 27,84\% (SD $\pm 10,005 \%)$. Setelah dilakukan tindakan didapatkan kadar neutrofil tertinggi $45 \%$, kadar terendah $11 \%$, dan rerata $22,7 \%(\mathrm{SD} \pm 6,635 \%)$.

Implikasi klinis neutrofil yang menyusun $50-70 \%$ dari semua leukosit tergantung pada proses pematangan berurutan di sumsum tulang yang memrovokasi konversi mieloblas menjadi neutrofil matang. Proses pematangan tergantung pada faktor-faktor stimulasi yang berbeda termasuk granulocyte-macrophage-colony stimulating factor (GM-CSF) dan granulocyte-macrophagecolony stimulating factor (G-CSF), yaitu dua faktor pertumbuhan paling relevan dalam mengendalikan proses pematangan tersebut. Pematangan neutrofil meliputi: mieloblas, promielosit, mielosit, metamielosit, neutrofil batang, dan neutrofil bersegmen. Umur neutrofil berubah pada kanker dan hal ini terkait dengan pematangan, yaitu memanjang dari 7 jam dalam kondisi normal sampai 17 jam pada kanker. Penelitian lain melaporkan bahwa mayoritas neutrofil tetap berada di sumsum tulang, misalnya pada tikus hanya 1-2\% beredar di darah tepi. Pelepasan neutrofil dari sumsum tulang tergantung pada serangkaian faktor stimulasi dan sitokin termasuk IL-23, IL-17, G-CSF; dan reseptor kemokin CXC. Pembentukan dan pematangan neutrofil memiliki implikasi 
penting dari desain strategi terapeutik hingga pemanfaatan ekspresinya sebagai biomarker prognostik. ${ }^{14-16}$

Peran neutrofil pada kanker bersifat multifaktorial dan belum sepenuhnya dipahami. Neutrofil mencerminkan keadaan peradangan inang, yang merupakan ciri khas kanker. Sel-sel ini dapat berpartisipasi dalam berbagai tahap proses onkogenik termasuk inisiasi tumor, pertumbuhan, proliferasi, atau penyebaran metastatik. Secara umum neutrofil memainkan peran sentral dalam peradangan di dalam tumor karena sel-sel ini tertarik oleh ligan CXCR2 seperti CXCL1, CXCL2 dan CXCL5. Inisiasi tumor dapat dipromosikan oleh bahan-bahan yang dilepaskan neutrofil seperti spesies oksigen reaktif (ROS), spesies nitrogen reaktif (RNS), atau protease. Mekanisme yang relevan ialah induksi angiogenesis. Berkurangnya jumlah neutrofil atau pemblokiran CXCR2 akan menurunkan proses angiogenesis. Beberapa faktor yang memediasi angiogenesis termasuk produksi faktor pertumbuhan endotel vaskular A (VEGFA), prokineticin 2 (PROK2), atau MMP9. Neutrofil dapat memfasilitasi proliferasi selsel tumor dengan menurunkan sistem kekebalan. Respons antitumor dari limfosit CD8 daan limfosit $\mathrm{T}$ dapat ditekan oleh nitrik oksida sintetase (iNOS) atau arginase 1 (ARG1) yang dilepaskan oleh neutrofil di bawah stimulasi oleh TGF $\beta$. Neutrofil juga menghasilkan MMP9 yang memiliki peran penting dalam inisiasi tumor. Selain itu proliferasi tumor dapat dimediasi oleh degradasi substrat reseptor insulin 1 (IRS1), dan aktivasi pensinyalan PI3K karena transfer neutrofil elastase ke sel kanker. Produksi iNOS juga dapat dirangsang dalam neutrofil oleh peningkatan regulasi reseptor tirosin kinase MET. Neutrofil juga dapat memotivasi penyebaran metastasis dengan menghambat fungsi sel-sel natural killer dan memfasilitasi ekstravasasi sel tumor. ${ }^{14-16}$

Dari paparan di atas dapat disimpulkan bahwa peran neutrofil terhadap kanker sangat kompleks. Beberapa penelitian bahkan telah menunjukkan bahwa neutrofil dapat menghambat penyebaran metastasis, seperti halnya pada kanker paru. Terda- patnya perbedaan fungsi ini dapat dikaitkan dengan keberadaan berbagai subpopulasi neutrofil. ${ }^{15}$

Pada penelitian ini, data neutrofil sebelum dan sesudah tindakan diuji dengan uji $\mathrm{t}$ berpasangan menyatakan terdapat perbedaan yang sangat bermakna dari kadar neutrofil sebelum dan setelah tindakan $(P<$ 0,001) (Tabel 3) yaitu kadar neutrofil mengalami penurunan yang sangat bermakna pasca tindakan (Gambar 1).

Mengingat berbagai peran neutrofil dalam perkembangan dan perkembangan kanker, beberapa kelompok akhir-akhir ini mengeksplorasi peran neutrofil dan penanda lain dari peradangan inang pada hasil klinis. Dengan demikian, jumlah neutrofil yang meningkat merupakan faktor prognostik yang merugikan dimasukkan dalam skor prognostik kontemporer untuk kanker sel ginjal metastatik (mRCC) yang diobati dengan terapi yang ditargetkan. Selain itu, sebagian besar data tersedia untuk rasio neutrofil terhadap limfosit yang diukur dalam darah perifer, yang disebut rasio neutrofil-limfosit (NLR). Nilai NLR tinggi dikaitkan dengan hasil yang lebih buruk pada banyak tumor padat, baik pada stadium kanker stadium lanjut dan sangat lanjut. Temuan ini membuat NLR sebagai biomarker mudah untuk dievaluasi, dan memiliki potensi untuk identifikasi respon awal. $^{11,17}$

\section{SIMPULAN}

Berdasarkan hasil penelitian ini dapat disimpulkan bahwa terdapat penurunan kadar neutrofil darah perifer pada pasien kanker payudara stadium lanjut setelah dilakukan tindakan.

\section{DAFTAR PUSTAKA}

1. Bray F, Ferlay J, Soerjomataram I, Siegel RL, Torre LA, Jemal A. Global cancer statistics 2018: GLOBOCAN estimates of incidence and mortality worldwide for 36 cancers in 185 countries. CA Cancer J Clin. 2018; 68(6):394-424.

2. Sobri S, Azhar Y, Wibisana G, Rachman A. Manajemen Terkini Kanker Payudara 
(1st ed). Jakarta: Media Aesculapius, 2017; p. 1-2

3. Mantovani A, Marchesi F, Porta C, Sica A, Allavena P. Inflammation and cancer: breast cancer as a prototype. Breast. 2007; 16(Suppl2):S27-33.

4. Balkwill F, Mantovani A. Inflammation and cancer: back to Virchow. Lancet. 2001; 357:539-45.

5. Ozyalvalci G, Yesil C, Kargi E, Kizildag B, Kilitci A, Yilmaz F. Diagnostic and prognostic importance of the neutrofil lymphocyte ratio in breast cancer. Asian Pac J Cancer Prev. 2014;15(23): 10363-6

6. Coussens LM, Werb Z. Inflammation and cancer. Nature. 2002;420(6917):860-7.

7. Okuturlar Y, Gunaldi M, Tiken EE, Oztosun B, Inan YO, Ercan T, et al. Utility of peripheral blood parameters in predicting breast cancer risk. Asian Pac J Cancer Prev. 2015;16(6);2409-12

8. Gabay C, Kushner I. Acute phase proteins and other systemic responses to inflammation. N Engl J Med. 1999;340(6): 448-54.

9. Queen MM, Ryan RE, Holzer RG, KellerPeck CR, Jorcyk CL. Breast cancer cell stimulate neutrofils to produce oncostatin M: potential implication for tumor progression. Cancer Res. 2005; 65(19):8896-904.

10. Gemignani ML. Anatomy of the breast and axilla. In: Breast Disease. Georgetown:
Landes Bioscience, 2000; p. 2-7.

11. Atzpodien J, Royston P, Wandert T, Reitz M. Metastatic renal carcinoma comprehensive prognostic system. Br J Cancer. 2003;88(3):348-53.

12. Dahlan MS. Besar Sampel dan Cara Pengambilan Sampel dalam Penelitian Kedokteran dan Kesehatan (3rd ed). Jakarta; Salemba Medika, 2010.

13. Townsend CM, Beauchamp RD, Evers BM, Mattox KL. Sabiston Textbook of Surgery (19th ed). Philadelphia: Elsevier Saunders, 2012; p. 824-67.

14. Tavares-Murta BM, Candido-Murta EF. Systemic leukocyte alterations in cancer and their relation to prognosis. Open Cancer J. 2008;2(1):53-8.

15. Proctor MJ, McMillan DC, Morrison DS, Fletcher CD, Horgan PG, Clarke SJ. A derived neutrofil to lymphocyte ratio predicts survival in patients with cancer. Br J Cancer. 2012;107(4):695-9

16. Guthrie GJ, Charles KA, Roxburgh CS, Horgan PG, Mcmillan DC, Clarke SJ. The systemic inflammation-based neutrophil-lymphocyte ratio: experience in patients with cancer. Crit Rev Oncol Hematol. 2013;88(1):218-30.

17. Rodenhiser DI, Andrews JD, Vandenberg TA, Chambers AF. Gene signatures of breast cancer progression and metastasis. Breast Cancer Res. 2011;13(1): 201-8. 